\title{
KAJIAN HUBUNGAN KONSENTRASI AMMONIA DAN CHEMICAL OXYGEN DEMAND (COD) DALAM PENGOLAHAN AIR LIMBAH SECARA ANAEROB
}

\author{
Nur Indradewi O. ${ }^{1)}$ Hery Purnobasuki ${ }^{2}$, Eko Prasetyo K. ${ }^{3)}$, Arya Zulfikar P. ${ }^{4)}$, Indah \\ Purnamasari $^{5)}$, Mega Rosita ${ }^{6}$ \\ 13456)Ilmu dan Teknologi Lingkungan, Universitas Airlangga \\ ${ }^{2}$ Biologi, Universitas Airlangga \\ ${ }^{*}$ E-mail: nur_i_d_o@yahoo.com
}

\begin{abstract}
Abstrak
Amonia adalah inhibitor dari proses anaerobik. Penelitian ini bertujuan untuk menentukan pengaruh konsentrasi ammonia terhadap penyisihan Chemical Oxygen Demand (COD). Penelitian ini mengkaji air limbah sintetik dengan konsentrasi ammonia $2500 \mathrm{mg} / \mathrm{l}$ dan $5000 \mathrm{mg} / \mathrm{l}$. Volume air limbah sintetik dalam reaktor anaerobic adalah 10 liter. Waktu operas ional reaktor adalah 16 hari. Pada air limbah dengan konsentrasi ammonia $2500 \mathrm{mg} / \mathrm{l}$, di hari ke-0 nilai COD sebesar 3816,96 mg/l dan setelah hari ke-16 nilai COD turun menjadi 1023,97 mg/l. Pada air limbah dengan konsentrasi $5000 \mathrm{mg} / \mathrm{l}$, di hari ke-0 nilai COD sebesar $3453,44 \mathrm{mg} / \mathrm{l}$ dan setelah hari ke-16 nilai COD turun menjadi 833,467 mg/l. Berdasarkan data tersebut, efisiensi penyisihkan COD pada konsentrasi $2500 \mathrm{mg} / \mathrm{l}$ adalah $73,17 \%$ dan pada kosentrasi 5000 $\mathrm{mg} / \mathrm{l}$ adalah $75,86 \%$.
\end{abstract}

Kata kunci: Amonia, Anaerob, Penyisihan COD

\section{Abstract}

Ammonia is inhibitor in anaerobic process. This study aims to determine the effect of ammonia concentration on anaerobic Chemical Oxygen Demand (COD) removal. This study observed a synthetic wastewater with ammonia concentration $2500 \mathrm{mg} / \mathrm{l}$ and $5000 \mathrm{mg} / \mathrm{l}$. A synthetic waste water volume in the anaerobic reactor was 10 liters. The operational reactor time was 16 days. At ammonia concentration of $2500 \mathrm{mg} / \mathrm{l}$, COD levels at 0 day was $3816.96 \mathrm{mg} / \mathrm{l}$ and COD levels decreased to $1023.97 \mathrm{mg} / \mathrm{l}$ after 16 days. For ammonia concentration of $5000 \mathrm{mg} / \mathrm{l}$, COD levels at 0 day was $3453.44 \mathrm{mg} / \mathrm{l}$ and COD levels decreased 833,467 mg/l after 16 days. Based on these data, COD removal efficiency at a concentration of $2500 \mathrm{mg} / \mathrm{l}$ at $73.17 \%$ and a concentration of $5000 \mathrm{mg} / \mathrm{l}$ at $75.86 \%$.

Key words: Ammonia, Anaerob, COD removal 


\section{PENDAHULUAN}

Pengolahan limbah secara anaerobik adalah pengolahan limbah secara biologi yang memanfaatkan mikroorganisme untuk mendegradasi bahan organik dalam air limbah dengan kondisi sedikit atau tidak terdapat oksigen (Indriyati, 2005). Bahan organik dalam air limbah dapat diukur dengan oksidasi kimia menggunakan potassium dikromat disebut Chemical Oxygen Demand (COD). COD didefinisikan sebagai banyaknya oksigen yang dibutuhkan untuk oksidasi sempurna bahan organik dalam air limbah. Pengolahan limbah secara anaerobik memiliki beberapa faktor yang dapat menghambat mikroorganisme mendegradasi bahan organik. Salah satu dari faktor penghambat adalah ammonia pada konsentrasi tertentu. Konsentrasi ammonia dalam pengolahan secara anaerob dapat menjadi nutrisi bagi mikroorganisme tetapi dapat menjadi racun bagi mikroorganisme. Mikroorganisme pada penelitian ini berperan sebagai agen pendegradasi bahan organic yang diukur dengan parameter COD.

Menurut Rajagopal (2013), ammonia yang memiliki konsentrasi sebesar 50-200 mg/l bersifat penunjang bagi mikroorganisme, konsentrasi 200-1000 mg/l tidak memberikan pengaruh terhadap mikroorganisme, konsentrasi $1500-3000 \mathrm{mg} / \mathrm{l}$ bersifat inhibitor atau penghambat kinerja mikroorganisme pada ph tertentu, dan konsentrasi $>3000 \mathrm{mg} / \mathrm{l}$ bersifat racun bagi mikroorganisme. Konsentrasi ammonia yang terdapat pada air limbah berpengaruh terhadap kemampuan mikroorganisme mendegradasi bahan organik air limbah, sehingga konsentrasi ammonia mempengaruhi penyisihan COD air limbah yang dilakukan oleh mikroorganisme. Penelitian ini dilakukan dengan tujuan untuk mengetahui seberapa besar konsentrasi ammonia menghambat kemampuan degradasi bahan organik dalam reaktor yang diukur dengan parameter COD. Pada penelitian ini, konsentrasi ammonia dalam air limbah dikondisikan sebesar $2500 \mathrm{mg} / \mathrm{l}$ dan $5000 \mathrm{mg} / \mathrm{l}$. Penelitian dilakukan selama 16 hari dan pengukuran parameter dilakukan setiap 4 hari sekali. Parameter pada penelitian ini adalah konsentrasi COD, $\mathrm{pH}$, dan suhu.

\section{METODE}

Reaktor anaerobik yang digunakan pada penelitian ini dengan sistem batch. Reaktor memiliki kapasitas 12L. Air limbah yang digunakan merupakan air limbah sintetik yang memiliki konsentrasi ammonia $2500 \mathrm{mg} / \mathrm{l}$ dan $5000 \mathrm{mg} / \mathrm{l}$ masing-masing dengan volume 10L. Terdapat 2 reaktor yang digunakan, yaitu reaktor yang berisi air limbah dengan konsentrasi ammonia $2500 \mathrm{mg} / \mathrm{l}$ yang disebut sebagai reaktor 1 dan reaktor yang berisi air limbah dengan konsentrasi ammonia $5000 \mathrm{mg} / \mathrm{l}$ yang disebut reaktor 2. Komposisi air limbah sintetik terdiri dari susu instan, glukosa, $\mathrm{KNO}_{3}$, $\mathrm{Na}_{2} \mathrm{~S}_{2} \mathrm{O}_{3}, \mathrm{NaHCO}_{3}, \mathrm{NH}_{4} \mathrm{Cl}, \mathrm{MgSO}_{4}$ dan sludge dari rumah pemotongan hewan (Purnobasuki, et al., 2014). Reaktor dioperasikan selama 16 hari. Parameter yang diukur setiap 4 hari sekali adalah Konsentrasi COD menggunakan metode bikromat mengacu pada Metoda Penelitian Air (Anonim, 2005), pH, dan suhu.

\section{HASIL DAN PEMBAHASAN}

Pada penelitian ini, pengolahan limbah yang digunakan adalah pengolahan secara anaerob untuk menyisihkan konsentrasi COD yang terdapat pada limbah. Proses anaerob dapat dipengaruhi oleh beberapa faktor, diantaranya adalah $\mathrm{pH}$, temperatur, waktu tinggal hidrolik, alkalinitas, dan senyawa inhibitor (Indriyati, 2007). Faktor yang berpengaruh signifikan terhadap proses anaerob adalah adanya senyawa inhibitor (Chen et al., 2008).

Pada proses anaerob sendiri, terutama pada saat asidogenesis, terdapat proses perombakan senyawa protein yang memberikan hasil samping berupa senyawa amonia. Senyawa ammonia merupakan salah satu senyawa inhibitor proses anaerob ketika mencapai konsentrasi tertentu. Pada penelitian ini, konsentrasi ammonia pada air limbah dalam reaktor dikondisikan sebesar $2500 \mathrm{mg} / \mathrm{l}$ dan $5000 \mathrm{mg} / \mathrm{l}$. Pada masing-masing reaktor 
tersebut, dilakukan pemantauan konsentrasi COD dalam air limbah setiap 4 hari 1 kali selama 16 hari. Hasil penelitian dapat dilihat pada pembahasan berikut.

\section{Penyisihan Konsentrasi COD pada Air Limbah Dengan Konsentrasi Ammonia 2500 $\mathrm{mg} / \mathbf{l}$}

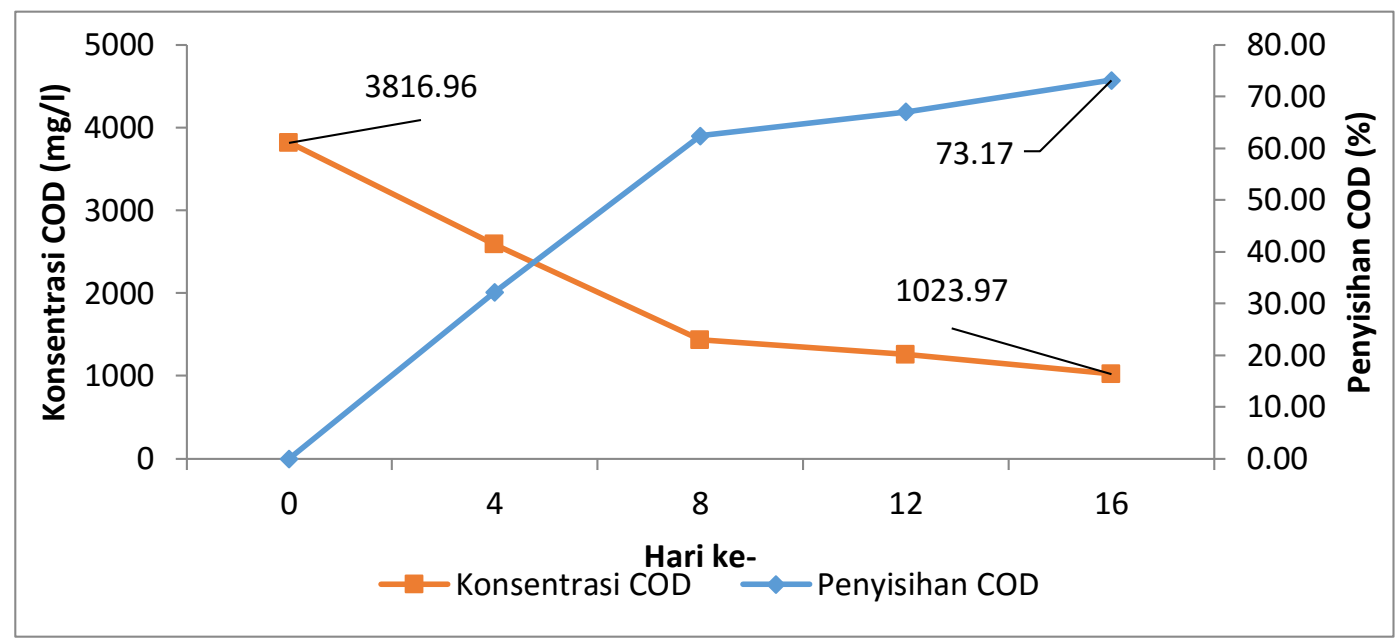

Gambar 1. Penyisihan COD pada Reaktor 1

Pada Gambar 1 dapat diketahui bahwa konsentrasi awal COD pada air limbah dengan konsentrai ammonia $2500 \mathrm{mg} / \mathrm{l}$ adalah sebesar $3816,96 \mathrm{mg} / \mathrm{l}$. Selama 16 hari penelitian, konsentrasi COD terus mengalami penurunan hingga mampu menyisihkan sebesar $73,17 \%$, yaitu menjadi 1023,97 mg/l. Penyisihan COD yang terjadi akibat adanya aktivitas mikroorganisme anaerob dalam air limbah yang berasal dari rumah pemotongan hewan. Mikroorganisme tersebut dapat mendegradasi bahan organik yang terdapat dalam air limbah secara optimal hingga mencapai penyisihan sebesar $73,17 \%$. Hasil yang sama juga terdapat pada penelitian yang dilakukan oleh Kim et al. (2015). Hasil penelitian yang dilakukan oleh Kim et al., (2015) menunjukkan bahwa reaktor anaerobik berisi limbah dengan konsentrasi ammonia tinggi dengan penambahan mikroorganisme dari rumah pemotongan hewan mampu menyisihkan COD pada air limbah sebesar $\pm 62 \%$ pada hari ke-15. Pada reaktor 1 , konsentrasi ammonia air limbah adalah 2500 mg/l. Menurut Rajagopal (2013), ammonia pada konsentrasi ini dapat menjadi penghambat proses pertumbuhan mikroorganisme anaerobik. Berdasarkan penelitian yang telah dilakukan, konsentrasi ammonia sebesar $2500 \mathrm{mg} / \mathrm{l}$ masih belum menjadi inhibitor terhadap aktivitas mikroorganisme dalam mendegradasi COD pada air limbah. Kemampuan penyisihan ini juga dipengaruhi oleh kondisi reaktor seperti $\mathrm{pH}$ dan suhu. Data $\mathrm{pH}$ untuk reaktor air limbah dengan konsentrasi ammonia $2500 \mathrm{mg} / \mathrm{l}$ berkisar antara 5 dan 6 seperti terlihat pada Gambar 2. Pada hari ke-0 pH air limbah adalah 6 dan pada hari ke-16 pH air limbah adalah 5. Nilai pH ini dikatakan asam, sehingga proses yang terjadi di dalam reaktor hingga hari ke-16 berada pada tahapan asidogenesis. Sedangkan suhu air limbah dalam reaktor selama 16 hari penelitian cenderung stabil seperti yang terlihat pada Gambar 3. Reaktor 2 berisi air limbah dengan konsentrasu ammonia sebesar 5000 mg/l. Pada penelitian sebelumnya dikatakan bahwa ammonia pada konsentrasi ini dapat menjadi inhibitor pada proses anaerob. Sheng et al., (2013) melakukan penelitian tentang pengaruh konsentrasi ammonia terhadap proses anaerobik, dan hasilnya menyatakan bahwa konsentrasi ammonia di atas $3780 \mathrm{mg} / \mathrm{l}$ dapat menjadi inhibitor pada proses metanogenesis. Begitu juga menurut Liu \& Sung (2002), konsentrasi ammonia dapat menjadi inhibitor pada proses metanogenesis apabila telah melebihi 4000 $\mathrm{mg} / \mathrm{l}$. 


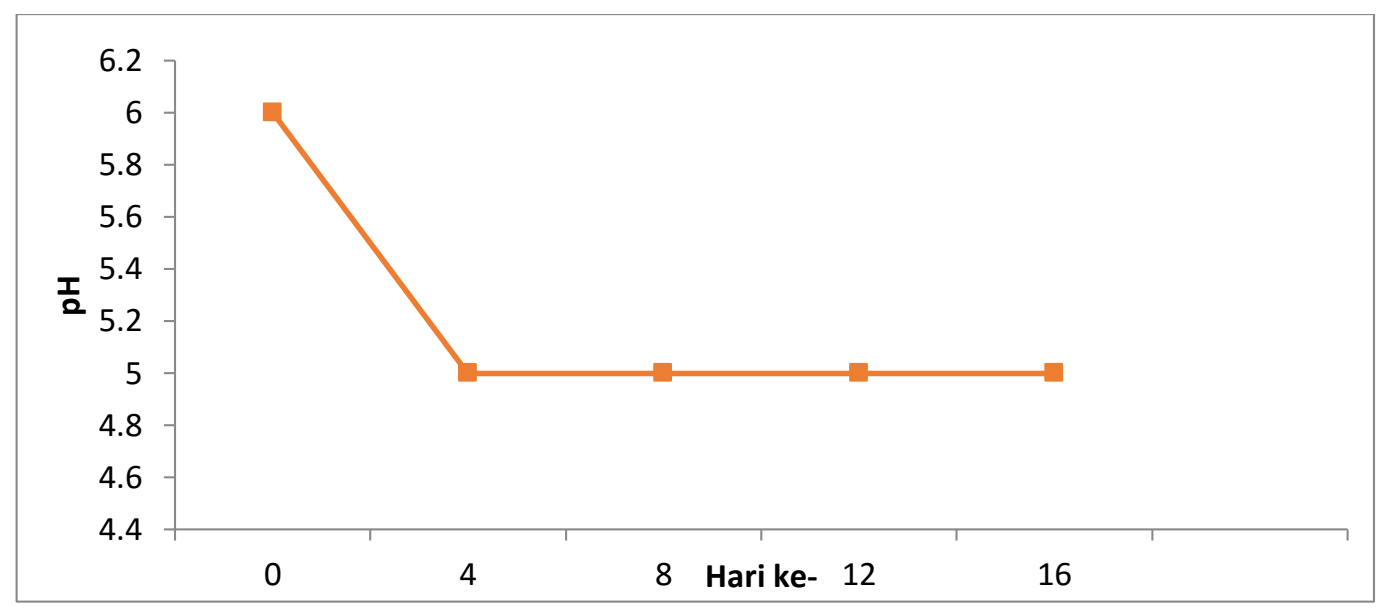

Gambar 2. Kondisi pH pada Reaktor 1

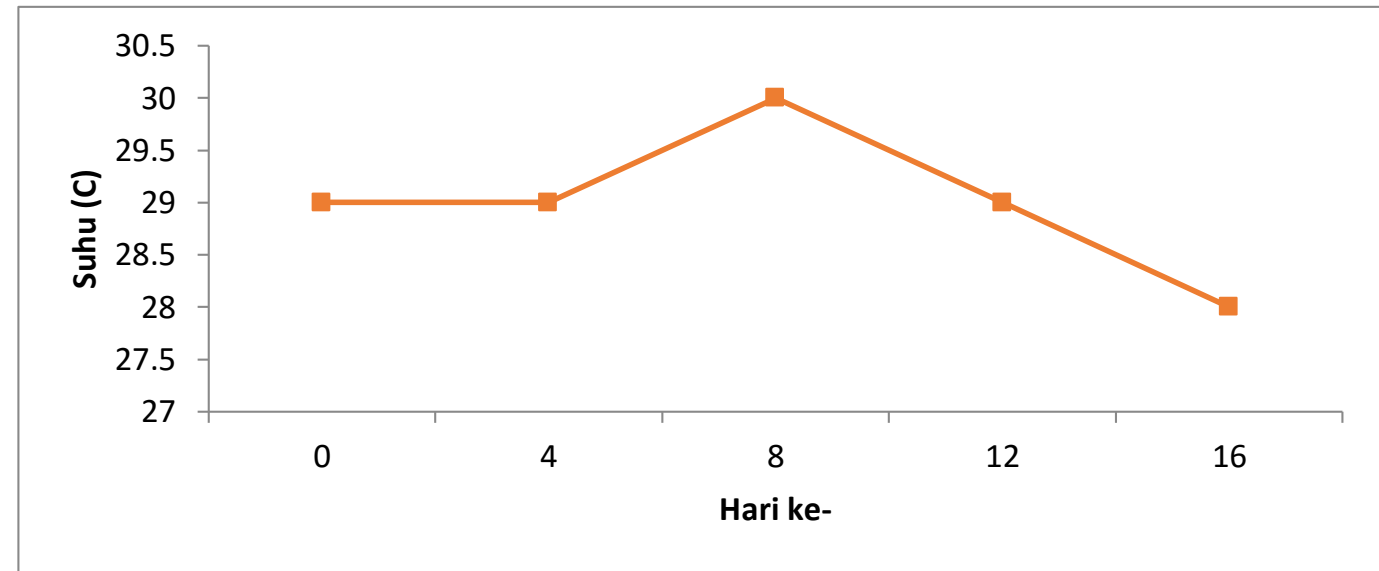

Gambar 3. Kondisi suhu pada Reaktor 1

Penyisihan Konsentrasi COD pada Air Limbah Dengan Konsentrasi Ammonia 5000 mg/l

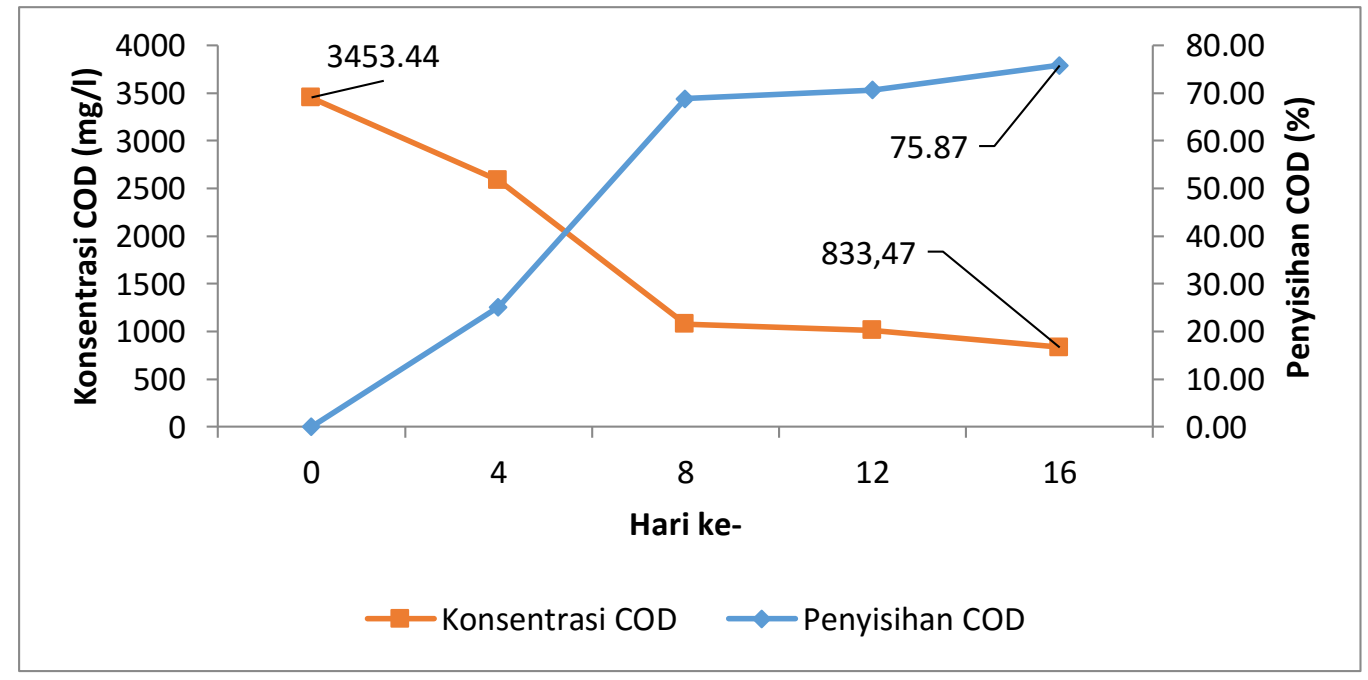

Gambar 4. Penyisihan COD pada Reaktor 2 
Peristiwa terhambatnya proses metanogenesis dapat ditandai dengan semakin tinggi konsentrasi COD dalam air limbah, yang diakibatkan terakumulasinya asam lemak bebas hasil proses asidogenensis yang tidak terkonversi menjadi biogas karena terhambatnya proses metanogenesis. Pada penelitian ini, konsentrasi COD pada air limbah dapat disisihkan meskipun konsentrasi ammonia dalam reaktor mencapai $5000 \mathrm{mg} / \mathrm{l}$. Pada Gambar 4, konsentrasi awal COD pada air limbah sebesar 3453,44 mg/l. Konsentrasi COD pada air limbah di dalam reaktor mengalami penurunan hingga pada hari ke-16. Konsentrasi COD dapat disisihkan sebesar $75,87 \%$ atau menjadi 833,47 mg/l. Besarnya persentase penyisihan pada reaktor 1 dan 2 tidak berbeda jauh. Hal ini disebabkan karena kemampuan agen pendegradasi COD pada kedua reaktor adalah sama. Agen pendegradasi COD pada air limbah di dalam reaktor adalah mikroorganisme anaerob yang berasal dari rumah pemotongan hewan, baik pada reaktor 1 maupun reaktor 2 . Mikroorganisme tersebut diambil dari sludge rumah pemotongan hewan. Mikroorganisme tersebut mampu menyisihkan bahan organik dalam limbah secara anaerobik hingga 85\% (Ortner et al., 2014). Pada konsentrasi ammonia di dalam air limbah tinggi, mikroorganisme tersebut masih mampu mendegradasi bahan organik pada air limbah hingga terjadi penyisihan konsentrasi COD.

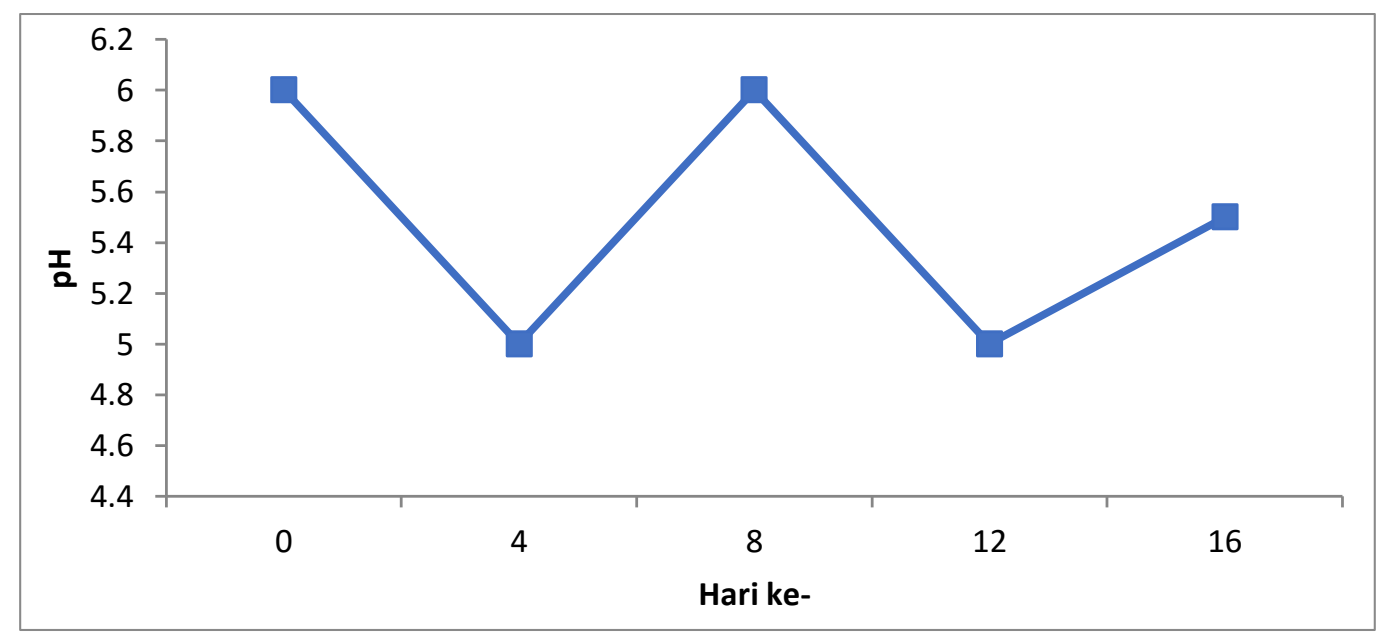

Gambar 5. Kondisi pH pada Reaktor 2

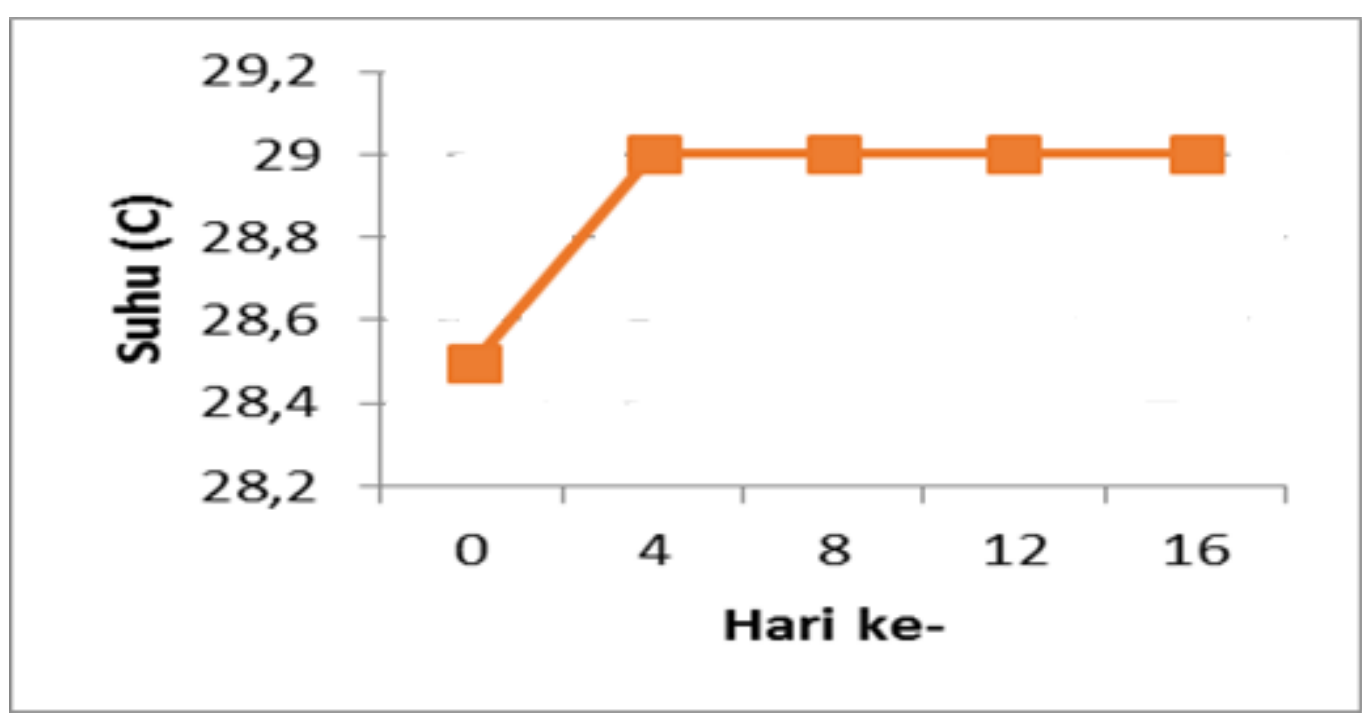

Gambar 6. Kondisi suhu pada Reaktor 2 


\section{KESIMPULAN}

Berdasarkan penelitian yang telah dilakukan dan pembahasan di atas, dapat diketahui bahwa konsentrasi ammonia dapat mempengaruhi kemampuan penyisihan COD pada reaktor anaerobik. Pada ammonia konsentrasi 2500 $\mathrm{mg} / \mathrm{l}$ hari ke 0 kadar COD sebesar 3816,96 mg/l dan pada hari ke 16 kadar COD sebesar 1023,97 $\mathrm{mg} / \mathrm{l}$. Untuk ammonia konsentrasi $5000 \mathrm{mg} / \mathrm{l}$, hari ke 0 kadar COD sebesar 3453,44 mg/l dan pada hari ke 16 kadar COD sebesar 833,467 $\mathrm{mg} / \mathrm{l}$.

\section{DAFTAR PUSTAKA}

Anonim. 2005. Standard Methods For The Examination of Water and Wastewater. American Public Health Association.

Chen Y., Cheng J. J., dan Creamer K. S. 2008. Inhibition of Anaerobic Digestion Process: A Review. Bioresource Technology 99, hal. 4044-4064.

Indriyati. 2005. Pengolahan Limbah Cair Organik Secara Biologi Menggunakan Reaktor Anaerobik Lekat Diam. JAI, 1(3), hal. 340-343.

Indriyati. 2007. Unjuk Kerja Reaktor Anaerob Lekat Diam Terendam Dengan Media Penyangga Potongan Bambu. Jurnal Teknologi Lingkungan 8(3), hal. 217222.

Kim, T., An, J., Jang, J. K., Chang, I. S. 2015. Coupling of Anaerobic digester and microbial fuel cell for COD removal and ammonia recovery. Bioresource Technology.

http://dx.doi.org/10.1016/j.biortech.201 5.06.009.

Liu, T., \& Sung, S. 2002. Ammonia inhibition on thermophilic aceticlastic methanogens. Water science and technology, 45(10), hal. 113-120.

Ortner, M., Leitzinger, K., Skupien, S., Bochmann, G., Fuchs, W. 2014. Efficient Anaerobic Mono-digestion of $N$-rich slaughterhouse waste: Influence of Ammonia, temperature and trace elements Bioresource Technology 174, hal. 222-232.

Purnobasuki, H., Oktavitri, N. I., Kuncoro, E. P., Asmara, A. A., Rafsanjani, S. I. 2014. Ammonia and organic compound removal from dairy milk simulation wastewater by coconut shell (Cocos nucifera). Journal of Chemical and Pharmaceutical Research, 6(12), hal. 619-624.

Rajagopal R., Masse D.I., dan Singh G. 2013. A Critical Review On Inhibition of Anaerobic Digestion Process by Excess Ammonia. Bioresource Technology 143, hal. 632-641.

Sheng, K., Chen, X., Pan, J., Kloss, R., Wei, Y. 2013. Effect of ammonia and nitrate on biogas production from food waste via anaerobic digestion. Biosystem Engineering 116, hal. 205-212 